\title{
Shortest Path Search Futsal Field Location With Dijkstra Algorithm
}

\author{
Delpiah Wahyuningsih**1, Erzal Syahreza ${ }^{2}$ \\ ${ }^{1}$ STMIK Atma Luhur Pangkalpinang; J1 Jend Sudirman Selindung, 0717-433506, Indonesia \\ ${ }^{2}$ Information Technology, Pangkalpinang, Indonesia \\ e-mail: *11 delphibabel@atmaluhur.ac.id, ${ }^{2}$ 1311500083@mahasiswa.atmaluhur.ac.id
}

\begin{abstract}
Abstrak
Kota Pangkalpinang merupakan kota dimana tempat penyewaan lapangan futsal sedang mengalami perkembangan dan peningkatan. Banyaknya para pecinta olahraga futsal dari luar kota Pangkalpinang, khususnya yang kurang mengetahui jalanan di kota Pangkalpinang akan sedikit kesulitan dalam mengakses tempat-tempat lapangan futsal di kota ini karena tidak mengetahui secara detail informasi mengenai rute menuju lapangan futsal tersebut. Penelitian ini dapat memudahkan pemain futsal dalam pencarian jalur terpendek lapangan futsal dengan algoritma dijkstra. Algoritma dijkstra yang menentukan jalur terpendek dengan menghitung node-node yang dilewati dari node awal sampai node yang dituju. Algoritma Dijkstra dengan cara membentuk node graph, simpul baru kemudian melakukan perhitungan jumlah simpul yang akan membentuk node baru untuk penentuan node yang akan dilalui sehingga algoritma dijkstra menemukan node terkecil yang akan terbentuk jalur terpendek pada sistem informasi geografis. Sistem ini menampilkan rute terpendek dari posisi user berada menuju ke lapangan futsal yang menjadi tujuan yang ada di kota Pangkalpinang dan sekitarnya.
\end{abstract}

Kata kunci-Algoritma Dijkstra, Jalur Terpendek, Lapangan Futsal.

\begin{abstract}
Pangkalpinang City is a city where futsal field rentals are experiencing growth and improvement. The number of lovers of futsal sport from outside Pangkalpinang city, especially those who are less aware of the streets in Pangkalpinang city will have little difficulty in accessing futsal field places in this city because they do not know in detail information about the route to the futsal field. This research can facilitate futsal players in searching shortest path futsal field with algorithm dijkstra. The dijkstra algorithm determines the shortest path by computing the nodes passed from the initial node to the destination node. Dijkstra algorithm by forming the node graph, the new node then perform the calculation of the number of nodes that will form a new node for the determination of the node to be passed so that the algorithm dijkstra find the smallest node that will form the shortest path in the geographic information system. This system displays the shortest route from the user position to the futsal field which is the destination in the city of Pangkalpinang and surrounding areas.
\end{abstract}

Keywords - Dijkstra Algorithm, Shortest Path, Futsal Field. 


\section{INTRODUCTION}

The technology sophiticattion is growing very rapidly, this situation is increasingly encouraging people to continue to perform various experiments and research for the development and discovery of new ways to provide benefits to facilitate the running activities. In the field of information technology in this era of super fast, the speed of information access has become a popularity in the world of learning. Learning is always associated with the sophiticattion and utilization of technology that is growing very rapidly.

Today most of the people from teenagers to the elderly have used the internet in their daily lives, not only easy to access but also greatly save time and cost, as with the Android-based smartphone. Android-based smartphones currently mushrooming in the community, especially among teenagers

Applications on android has a lot to provide convenience for the user, one of which utilization map or map to search a location that will get by the user. The map currently not like the old paper-based manuals were taken anywhere to view a location that will be addressed, and with the development of technology emerged a technology called geographic information system.

Geographic information system known GIS. GIS is that leverages the geography of the region digitally which simplifies the have. For example searching the location of tourist attractions, search for restaurants, futsal field search and many more examples of utilization of geographic information systems. The rapid development of technology through GIS the use of algorithm was applied in the shortest alternative path.

Pangkalpinang region is the capital city of Bangka Island. Pangkalpinang has a lot of futsal field and interest by teenagers and futsal field business is growing in Pangkalpinang area, but there are obstacles in finding futsal field for teenager or futsal player. The players futsal both from the Pangkalpinag region itself and from outside Pangkalpinang less know the location of futsal field location anywhere and how much the cost and facilities owned futsal field that will be leased. Usually futsal players to ask other teenagers or to the public about futsal field information and rentals. Often the information obtained from the public is not up-to-date and accurate so it becomes a constraint and difficulty for futsal players to know the location of futsal field and other information for futsal field lease. This triggers the authors to apply a geographic information system technology with the shortest path to the futsal field to be targeted by applying the algorithm dijkstra.

Dijkstra's algorithm looks for the shortest path in a number of steps. The algorithm uses the Greedy principle which states that at each step we choose the minimum-weighted side and put it into the solution set [1].

The application of the dijkstra algorithm to the futsal field search in the Pangkalpinang area provides complete information about the location of the futsal field and provides the shortest route of the location of the futsal field in Pangkalpinang and surrounding areas. It is also very helpful for futsal players to be able to find up-to-date and accurate information about rental information, faisilitas, location and the shortest route to futsal field in Pangkalpinang area.

There are several research related to geographic information system that is the first research conducted by Yogi Primadasa [2], the results obtained in this study is Geographic Information System Application that is web-based is able to relate the channel information to PT. Distribution of Coca Cola about which path can be taken to speed up the distribution process by following the shortest route path using Dijkstra algorithm that has been produced. Second, Research conducted Made Leo Radhitya and Agus Harjoko [3] The result of this research is geographic information system using $\mathrm{C} 4.5$ algorithm with result of evaluation of system performance, got average value for accuracy equal to 0,84 , average value for precision equal to 0,61 , average value for recall of 0.68 and the average value of F-measure obtained by 0.59 in

IJCCS Vol. 12, No. 2, July 2018: $161-170$ 
the value of 0 to 1 . Third, Research conducted by Heriadi and Delpiah Wahyuningsih [4], the results obtained in this study is the application of geographic information systems that can provide information on the location of the mining area using the media website. By utilizing this WebGIS, the location point of the mining area will be displayed as detailed as possible in a simple web display so easy to use government and community. This application will provide easy access to information quickly and accurately to save costs and time. Application of this application will have a positive impact for the people and government of Central Bangka. Fourth, Research conducted by Antonio Gusmao, Sholeh Hadi Pramono, Sunaryo [5], the results obtained in this study is to display digital maps on the web with the Google Maps API. Apache Web server to handle user requests to retrieve data from MySQL database. Apache web server and MySQL database are already integrated in XAMPP. Dijkstra's algorithm can perform the shortest path search from the position of the user's starting point to the location object with the accuracy of the average distance of $0.03 \%$ to the measurement. The result of the shortest route is distance, route and travel time with the average speed of vehicles specified. Fifth, Research conducted by Wirriyawan Azzaki, Delpiah Wayuningsih [6], the results obtained in this study is to produce a web-based geographic information system that can display data in the form of maps in Pangkalpinang and provide information where the car rental can be accessed through webgis for 24 hours and there is a download facility in pmapper application, so it can store the map information.

\section{METHODS}

\subsection{Dijkstra's Algorithm}

The dijkstra algorithm is one form of the greedy algorithm. This algorithm includes a graph search algorithm used to solve the shortest path problem with a single source on a graph that does not have a negative side cost, and produces a shortest path tree. This algorithm is often used in routing.

Dijkstra's algorithm looks for the shortest path in a number of steps. The algorithm uses the following greedy strategy. For each source node in the graph, this algorithm will find the path with minimum cost between the node and the other node. This algorithm can also be used to find the total cost (cost) of the shortest path formed from a node to a destination node. For example, if the node in the graph represents the city and the side weights represent the distance between the two cities flanking it, the Dijkstra algorithm can be used to find the shortest route between a city and another city [1]. According to Kurose and Ross inside Gede Saindra S [7]

\subsection{Graph}

Graph is a diagram that contains certainy information if it is correctly interpreted. Gaph is used to describe various structures. The goal is as a visualization of objects to be more easily understood [8].

Graph $G$ is defined as a set of sets $(V, E)$, written with $G=(V, E)$ notation, in which case $V$ is a non-empty set of vertices (nodes) and $\mathrm{E}$ is a set of sides (edges or arcs ) connecting a pair of vertices [8] [9].

According to the direction and the weight, the graph is divided into four parts: first, Graph is directed and weighted is a graph that each vertex (point) is represented by an arrow that is a directed curve and each side has a weight. For example in the picture shown:

$$
\begin{aligned}
V(G)= & \{1,2,3,4,5,6,7,8\} \\
E(G)=\{ & \{1,2],[1,3],[2,3],[2,4],[2,5],[3,4],[3,5],[3,6],[4,5],[4,6],[4,7],[5,6],[5,7], \\
& {[6,8],[7,8]\} }
\end{aligned}
$$


Each side at the graph point of equations (1) and (2) has different weights. As in picture 1 below.

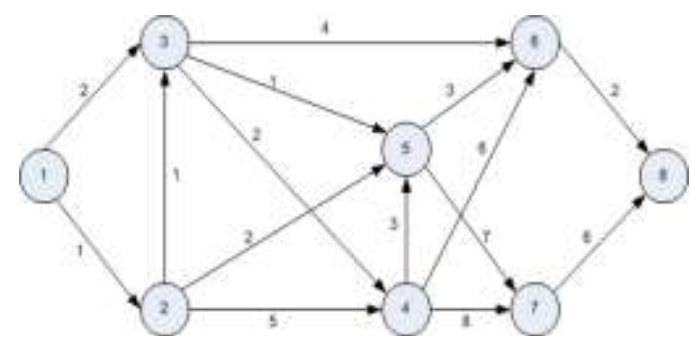

Figure 1. Examples of Graphs Traffic and Weight

Second, the Graph is not directional and weighs each side of the graph there is no arrow or a directed curve. The order of each vertex connected from each vertex is not addressed. Thus, $\mathrm{E}$ $(G)=\{[1,2]\}$ equals $E(G)=\{[2,1]\}$. And each side has different weights or values, like the example in figure 2.

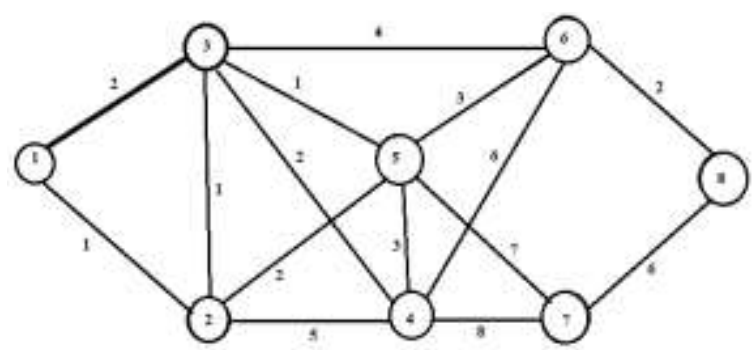

Figure 2. The Graph Example is not directional and weighty

Third, directed and non-weighted Graph is a graph that each vertex represents an arrow showing a direction, but each side has no weight or value, as shown in Figure 3.

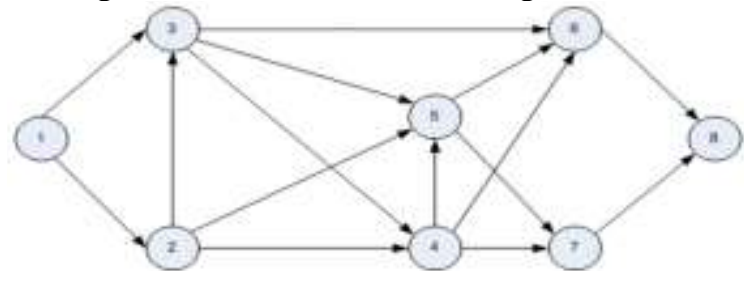

Figure 3. Graph samples are directed and not weighted

Fourth, the non-directional and non-weighted Graph is a gaph that each vertex is not represented by an arrow and each side has no weight or value, like figure 4 .

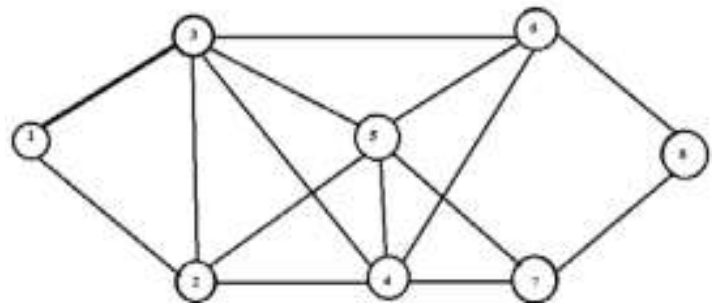

Figure 4. The Graph example is non-directional and does not weigh

\section{3 Shortest Path}

The shortest path is a matter of finding the path between two or more vertices on a weighted graph that combined the minimum weight of the graph side of the graph. In the 
weighted graph there are optimizations that can be expressed in the distance between cities, time of message delivery, cost and so on. In this case the weight must be positive, although in other ways it can be negative. The shortest path with the initial vertex $s$ and destination vertex $t$ is defined as the shortest path of $\mathrm{s}$ and $\mathrm{t}$ with minimum weight and a simple path. [10]

\subsection{The establishment of Dijkstra Graf}

There are several points futsal field objects in the city of Pangkalpinang and surrounding areas. From the point of location and roadmap in Pangkalpinang and surrounding cities in the graph for use in calculating Dijkstra's algorithm in order to get the fastest route from point of user to destination point. In point graph is a node or vertex, while a path is a line or edge connecting between points. To implement Dijkstra's algorithm in finding the fastest route required Dijkstra graph. Here is a Dijkstra graph or mapping of existing road routes in the city of Pangkalpinang and surrounding areas.

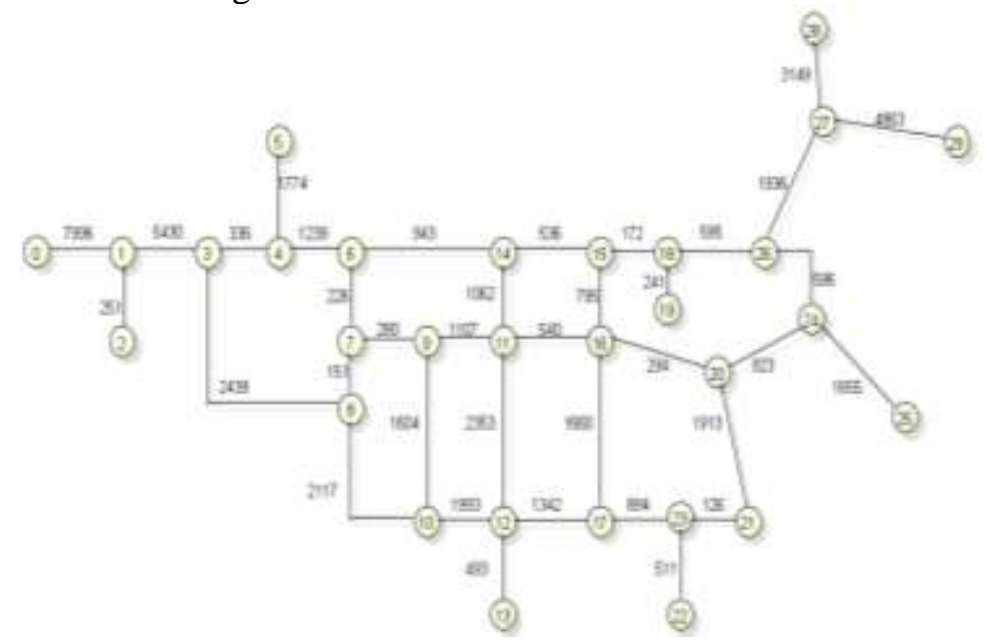

Figure 5. Graph Formation

From the graph modeling in figure 5, we can take a case example for example a user who wants to travel from node 15 to node 25 . The user wants the fastest path that can be passed. So we take a sample of two possible passable paths:

The first line on the graph is denoted from $15 \rightarrow 18 \rightarrow 26 \rightarrow 24 \rightarrow 25$.

The second line on the graph is notated from $15 \rightarrow 16 \rightarrow 20 \rightarrow 24 \rightarrow 25$.

From the two samples of the pathway, we get node 15, 16, 18, 20, 26, 24 and 25 samples. From the sample nodes can be made simple graph that only includes nodes and paths that lead to node 25 . Here is a graph that has been simplified with the mileage of each path in meters.

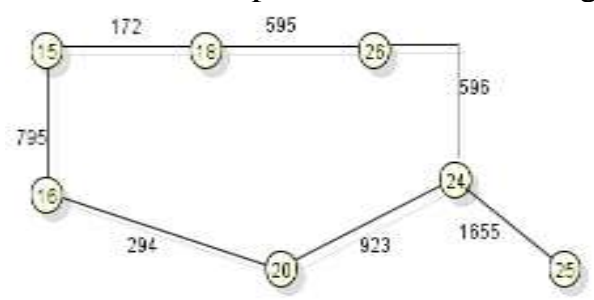

Figure 6. The graph is formed from node 15 to node 25

From Figure 6 the next system will perform calculations with Dijkstra algorithm. The following is a description of the steps in Dijkstra's algorithm to handle the case.

First, Input is the starting node, destination node and graph. In this case the initial node is node 15 , the destination node 25 while the graph input is a simple graph consisting of nodes 15 , $16,20,24,26,25$ and 18 along with the path that has the weight of the mileage. Second, the first step is to specify the initial node as found and then visited. In this case it means setting the node 
15 status to be found and then the status is visited. Meanwhile all other nodes have not found and have not been visited yet. The second step is to search for each node that can be reached directly from the node being visited. Because currently the node being visited is node 15 . So searches for each node that can be reached directly from node 15 . In this case found two nodes, namely node 16 and node 18 with has accumulated the current weight of $16=795$ and $18=172$. The accumulated weight is the total weights that can be reached from the initial node to the node through the route being traced.

The third step is that if the node obtained in the second step has not been found, then change the status to be found. nodes that have been found, then do the update on the weight, take a smaller weight. At this time the nodes obtained are node 16 and node 18, where the node has never been found before, then the two nodes are changed its status to be found.

The fourth step is to search the node that has the smallest weight of all nodes located on the status found then visit it. So for now the search will generate node 18 as the node with the least weight. Then the next system visited the node 18 . Next on node 18 is done again the second step, it will be found node 26 with accumulated weight of 767 . After that run the third step, then node 26 changed its status to be found. run the fourth step, where in this case the node located on the status found that is 26 and 16 . Then it will produce node 26 with the smallest weights and the system will visit node 26 . Then at node 26 is done back the second step, it will be found node 24 with weight accumulated 1363. After that run the third step, then the node 24 changed its status to be found. run the fourth step, where in this case the nodes located on the status found that is 24 and 16. Then will be node 16 with the smallest weight and the system will visit node 16. done again the second step is to search the node that can be achieved directly from node 16 . Then the system will find node 20 with node accumulated weight $20=1089$. Next run again the third step, then at node 20 changed its status to be found. The next step is executed again the fourth step, where in this case the nodes are located in the status found that is 24 and 20 . Then will be node 20 with the smallest weight and the system will visit node 20 . Then at node 20 is done back the second step, it will be found node 24 with the accumulated weight of 2012. After that run the third step, then the node 24 changed its status to be found. Whether in node 24 is done again the second step, it will be found node 25 . After that run the third step, then node 25 changed its status to be found.

Thus the route with the smallest weights that can be used to node 25 is $15 \rightarrow 18 \rightarrow 26 \rightarrow 24 \rightarrow 25$. The total weight of 2991 .

Table 1. Node Conditions At End of Search

\begin{tabular}{|l|l|l|l|}
\hline \multicolumn{1}{|c|}{ Node } & \multicolumn{1}{c|}{ Status } & Weight & \multicolumn{1}{c|}{ Route } \\
\hline 15 (origin) & Visited & 0 & 15 \\
\hline 18 & Visited & 172 & $15 \rightarrow 18$ \\
\hline 26 & Visited & 767 & $15 \rightarrow 18 \rightarrow 26$ \\
\hline 16 & Visited & 795 & $15 \rightarrow 16$ \\
\hline 20 & Visited & 2012 & $15 \rightarrow 16 \rightarrow 20$ \\
\hline 24 & Visited & 1363 & $15 \rightarrow 18 \rightarrow 26 \rightarrow 24$ \\
\hline 25 & Visited & 2991 & $15 \rightarrow 18 \rightarrow 26 \rightarrow 24 \rightarrow 25$ \\
\hline
\end{tabular}

From the description of steps Dijkstra algorithm in table 1 can be taken two conclusions that first of the two possible paths can be passed from node 15 to node 25 , then obtained the fastest path is the first path of the route $15 \rightarrow 18 \rightarrow 26 \rightarrow 24 \rightarrow 25$ with a distance of 2991 meters and second, in the worst case Dijkstra algorithm certainly find the best solution. The above case is almost the worst case, in which almost every node is visited to reach the destination node. 


\subsection{Analysis of Current System}

Activity Diagram of the existing system running in the community before the application of geographic information system location of futsal field with algorithm dijkstra android based in Pangkalpinang city. Can be seen in figure 7.

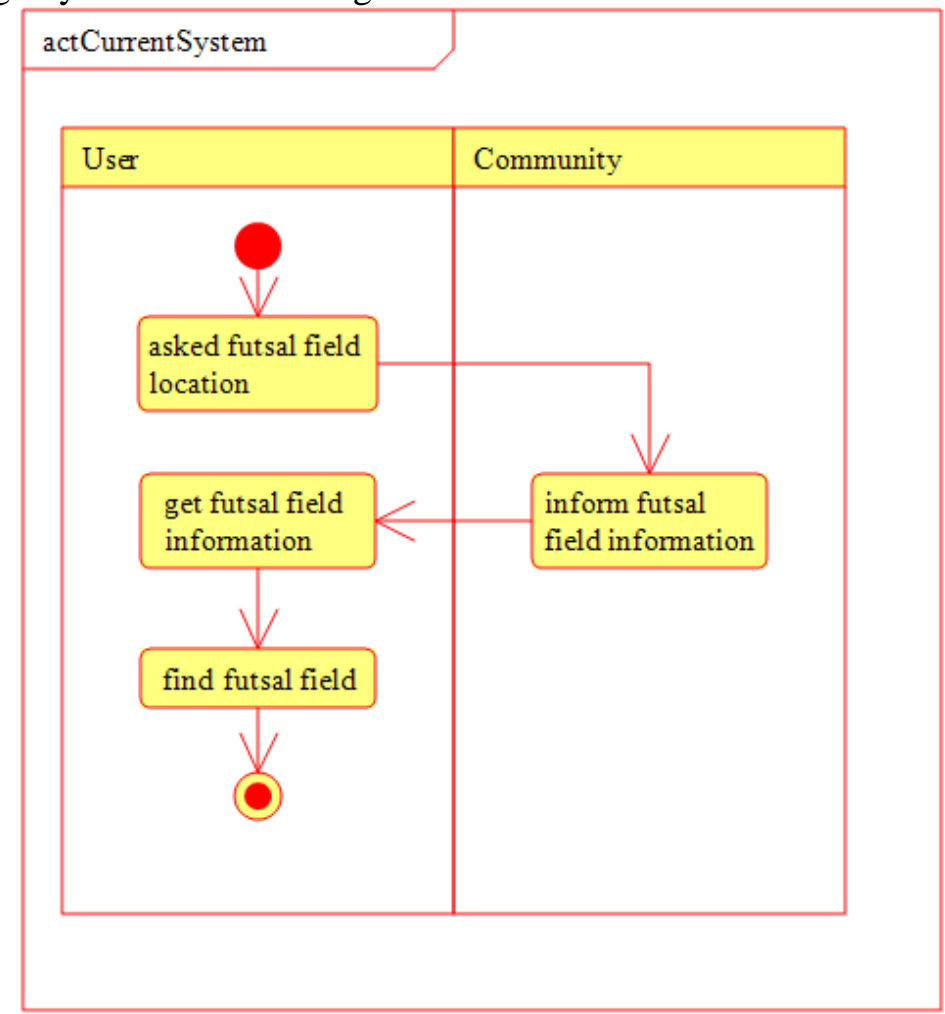

Figure 7. Activity Diagram The system is running

\subsection{Usecase Diagram}

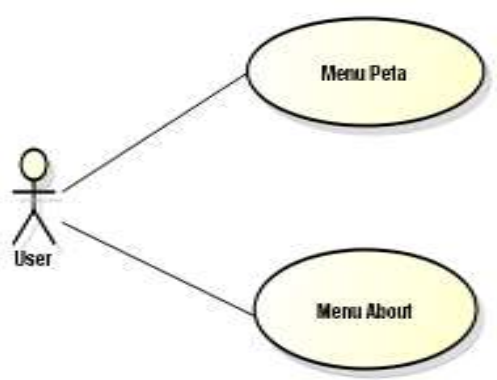

Figure 8. Use Case Proposed System

In Figure 8 describes on the map menu, contains about the list of futsal field in the city of Pangkalpinang and surrounding areas, maps indicate the location and the fastest route to futsal field. If you select the futsal by field and the tab on the map where the user is located, it will show the fastest route have chosen futsal location.

\subsection{Class Diagram}

Class diagram of geographic information application location of Android-based futsal field in Pangkalpinang city with Dijkstra algorithm, can be seen in figure 9. 


\begin{tabular}{|l|l|l|}
\multicolumn{1}{|c|}{ Futsal } & \multicolumn{1}{c|}{ graph } \\
\cline { 1 - 1 } $\begin{array}{l}\text { - futsal }: \text { string } \\
\text { - coordinate }: \text { string }\end{array}$ & $1 \quad$ coordinate $\quad \mathrm{m}$ & $\begin{array}{l}\text { - initial_node }: \text { int } \\
\text { - destination_node }: \text { int }\end{array}$ \\
$\begin{array}{l}\text { + save } 0 \\
\text { + view0 } 0\end{array}$ & $\begin{array}{l}\text { - path }: \text { string } \\
\text { - weight }: \text { double }\end{array}$ \\
\hline & & + search_path 0 \\
\hline
\end{tabular}

Figure 9. Class Diagram

2.7 Sequence Diagram

Sequence diagram of the program to be built on Map, can be seen in Figure 10.

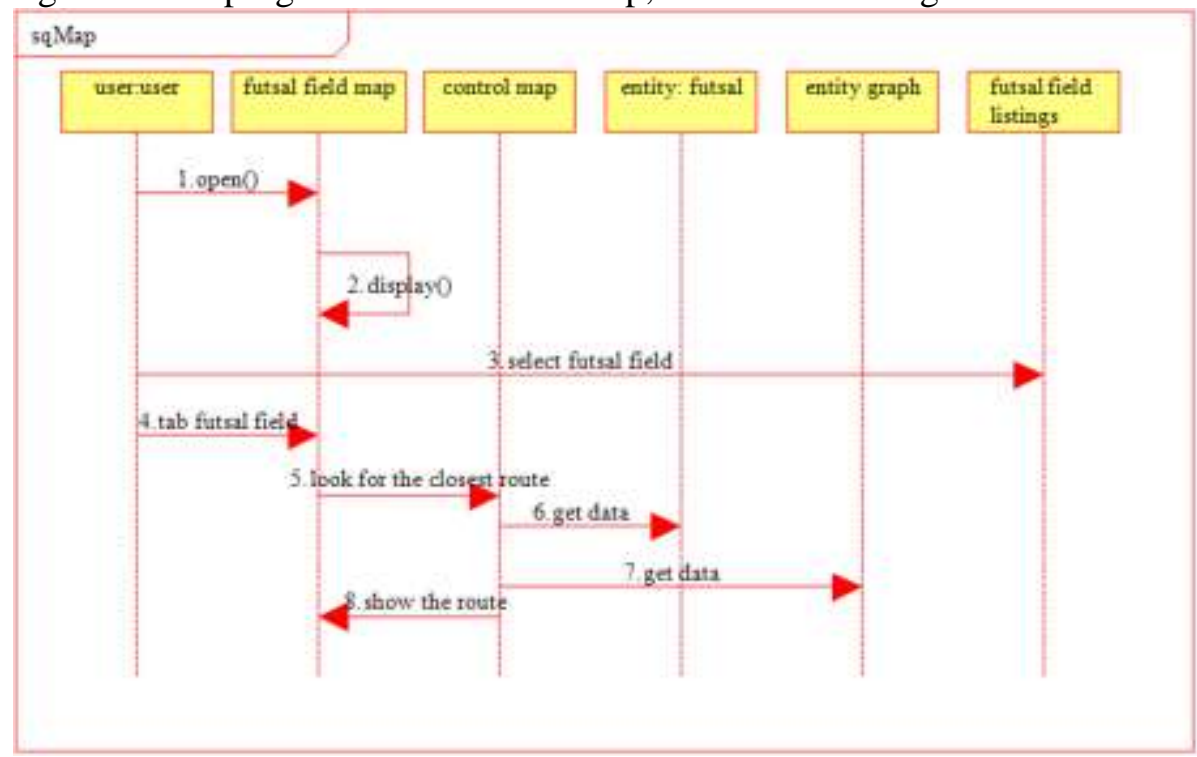

Figure 10 Sequence Map Diagram

\section{RESULT AND DISCUSSION}

\subsection{Map Menu}

This menu is the view when the user selects the map menu. In this menu the user can see the map and select the list view that is the list of futsal field in pangkapinang and surrounding areas, can be seen in Figure 11.

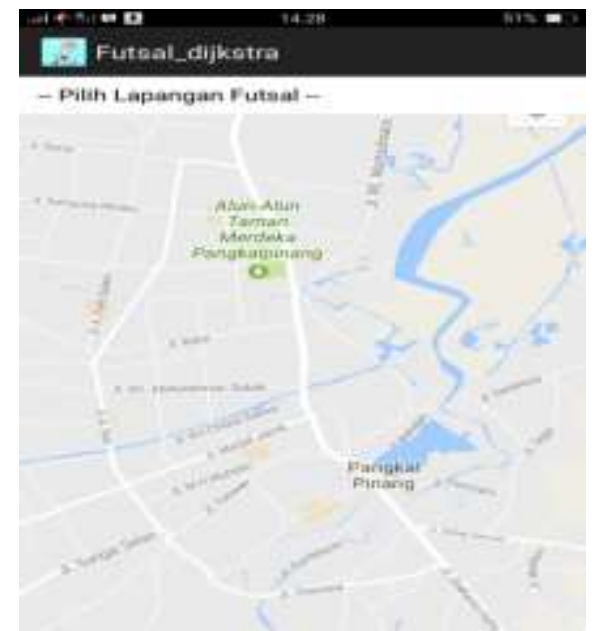

Figure 11 Map Menu View

3.2 Futsal Field List

IJCCS Vol. 12, No. 2, July 2018 : $161-170$ 
In this list there is a list of futsal fields in Pangkalpinang and surrounding areas that will be the destination user, can be seen in Figure 12.

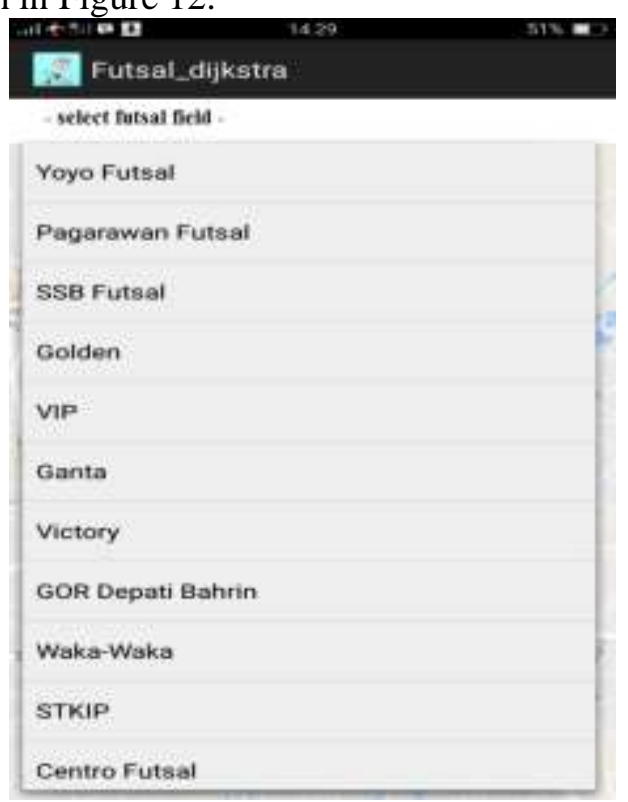

Figure 12 Display of futsal field list

3.3 The map shows the route of the dijkstra algorithm

Once described as above, in this application when the user clicks the selected futsal field and tap on the map for the user's position, then the next will show the fastest route from the user position to the selected futsal field, can be seen in Figure 13.

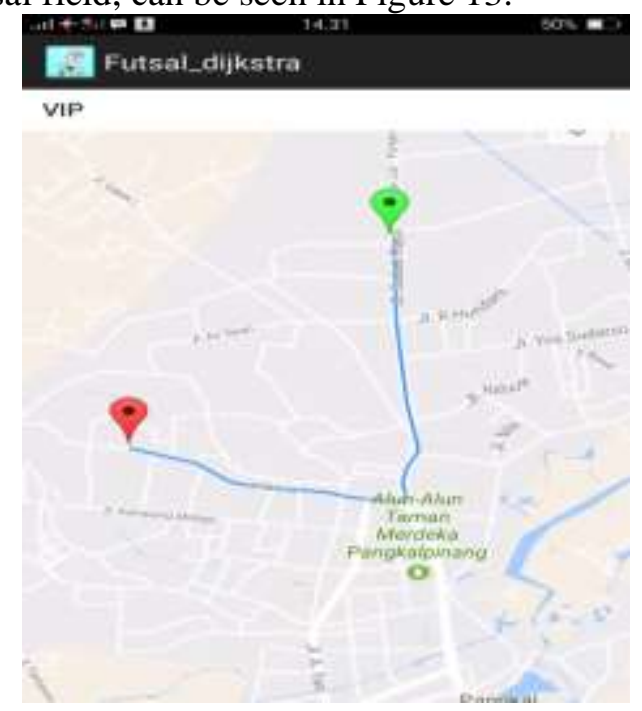

Figure 13 Fastest Route View

\section{CONCLUSIONS}

Based on the research and description above it can be concluded that Implementation of Dijkstra algorithm on search futsal field route in Pangkalpinang city and its surroundings can determine the fastest route from the user position to the location have chosen futsal field. And the application can display the user position and futsal field location, thus providing ease in accessing the location of the user's position. 


\section{ACKNOWLEDGEMENTS}

The authors would like to thank the Founder and STMIK Atma Luhur Team who have provided financial support during the authors doing this research.

\section{REFERENCES}

[1] S. Arifianto, "Sistem Aplikasi Penentuan Rute Terpendek Pada Jaringan Multi Moda Transportasi Umum Menggunakan Algoritma Dijkstra" Tesis Universitas Diponegoro Semarang 2012 [Online]. Available: http://eprints.undip.ac.id/36054/. [Accessed: 14Sept-2017]

[2] Y. Primadasa, "Pencarian Rute Terpendek Menggunakan Algoritma Dijkstra pada SIG Berbasis Web untuk Distribusi Minuman", Jurnal KomtekInfo Fakultas Ilmu Komputer Volume.2, No.2, $2015 \quad$ [Online]. Available: http://lppm.upiyptk.ac.id/komtekinfo/index.php/KOMTEKINFO/article/view/35. [Accessed: 14-Sept-2017]

[3] M. L. Radhitya and A. Harjoko, "Sistem Informasi Geografis Risiko Kemunculan Rip Current Menggunakan Decision Tree C4.5", IJCCS (Indonesian Journal of Computing and Cybernetics System)., vol.10, no.2, 2016 [Online]. Available: https://journal.ugm.ac.id/ijccs/article/view/15949. [Accessed: 9-Des-2017]

[4] Heriadi and D. Wahyuningsih, "Aplikasi Sistem Informasi Geografis Pemetaan Kawasan Pertambangan Timah Berbasis Web Studi Kasus Di Dinas Pertambangan Dan Energi Kabupaten Bangka Tengah", Jurnal Sisfokom, Vol 3 No 2 September 2014 [Online]. Available: http://jurnal.atmaluhur.ac.id/index.php/sisfokom/article/view/207. [Accessed: 14-Sept-2017]

[5] A. Gusmao, S. H. Pramono and Sunaryo, "Sistem Informasi Geografis Pariwisata Berbasis Web dan Pencarian Jalur Terpendek dengan Algoritma Dijkstra", Jurnal EECCIS Vol. 7, No. 2, Desember 2013 [Online]. Available: http://www.jurnaleeccis.ub.ac.id/index.php/eeccis/article/view/214. [Accessed: 14-Sept2017]

[6] W. Azzaki and D. Wahyuningsih, "Pencarian Lokasi Tempat Penyewaan Mobil Daerah Kota Pangkalpinang Berbasis Sistem Informasi Geografis", Teknosi, Vol. 02, No. 03 Desember $2016 \quad$ [Online]. Available: http://teknosi.fti.unand.ac.id/index.php/teknosi/article/view/75. [Accessed:13-Sept-2017]

[7] G. Saindra and R. Pulungan, "Reduksi Parameter Quality-Of-Service Menggunakan Rough-Set-Theory Dalam Simulasi Routing Algoritma Dijkstra", IJCCS (Indonesian Journal of Computing and Cybernetics System)., vol.6, no.1, 2012 [Online]. Available: https://journal.ugm.ac.id/ijccs/article/view/2143/1924. [Accessed: 9-Des-2017]

[8] Siringoringo and Y. B. Putra, "Penentuan Rute Terpendek Sistem Pengangkutan Sampah Kota Medan dengan Menggunakan Algoritma Dijkstra (Studi Kasus: Kecamatan Medan Baru)", Skripsi Universitas Sumatera Utara Medan 2014 [online]. Available: http://repository.usu.ac.id/handle/123456789/61481. [Accessed: 14-Sept-2017]

[9] Fitria and A. Triansyah, "Implementasi Algoritma Dijkstra dalam Aplikasi untuk Menentukan Lintasan Terpendek Jalan Darat Antar Kota di Sumatera Bagian Selatan", JSI (Jurnal Sistem Informasi), Vol.5, No.2, 2013 [Online]. http://ejournal.unsri.ac.id/index.php/jsi/article/view/840. [Accessed: 9-Des-2017]

[10] S. Andayani and E. W. Perwitasari, "Penentuan Rute Terpendek Pengambilan Sampah di Kota Marauke Menggunakan Algoritma Dijkstra", Seminar Nasional Teknologi Informasi dan Komunikasi Terapan (SEMANTIK), 2014 [Online]. http://eprints.dinus.ac.id/13736/. [Accessed:9-Des-2017] 